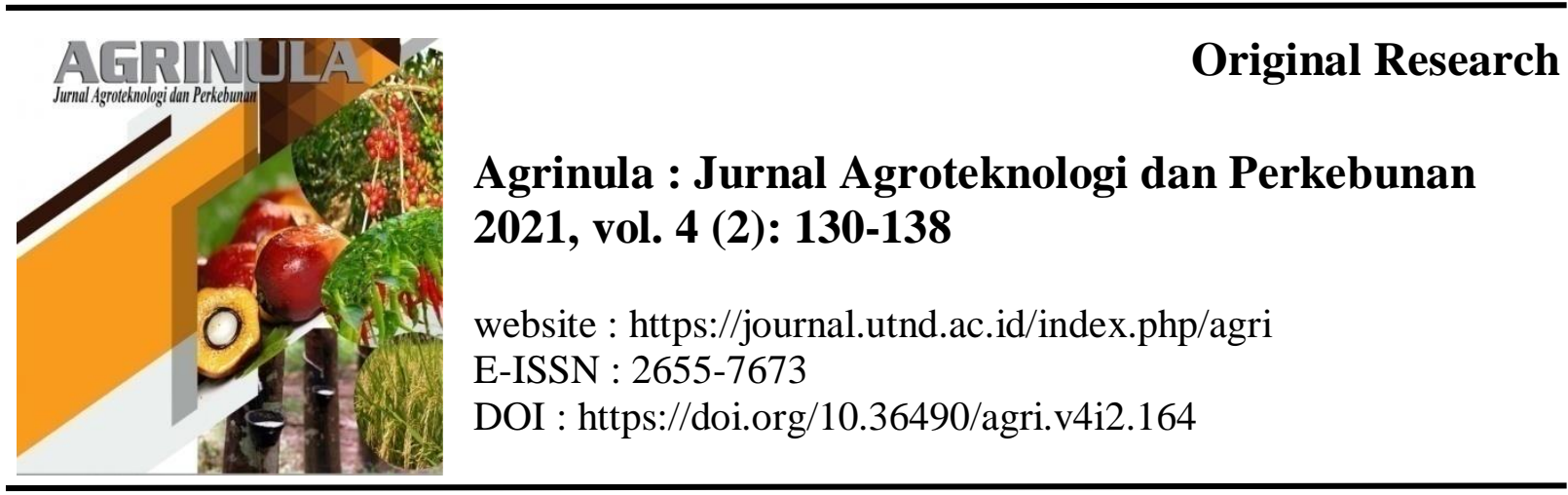

PENGARUH EKSTRAK BAWANG MERAH DAN ZAT PENGATUR TUMBUH AUKSIN TERHADAP PERTUMBUHAN SETEK Mucuna bracteata D.C

\title{
THE EFFECT OF SHALLOT EXTRACT AND AUXIN-PLANT GROWTH REGULATORS ON THE GROWTH OF Mucuna bracteata D.C.
}

\section{Silvana Prameswari \& Bayu Pratomo*}

Program Studi Agroteknologi, Fakultas Agro Teknologi, Universitas Prima Indonesia, Medan 20117, Sumatera Utara, Indonesia

*Koresponding author : bayupratomo@unprimdn.ac.id

\begin{tabular}{|c|c|}
\hline Informasi Artikel & ABSTRAK \\
\hline $\begin{array}{l}\text { Disubmit: } \\
\text { 15 Juni } 2021 \\
\text { Direvisi: } \\
\text { 25 Juli } 2021 \\
\text { Diterima: } \\
\text { 28 Juli 2021 } \\
\text { Dipublikasi: } \\
\text { 03 Agustus 2021 }\end{array}$ & 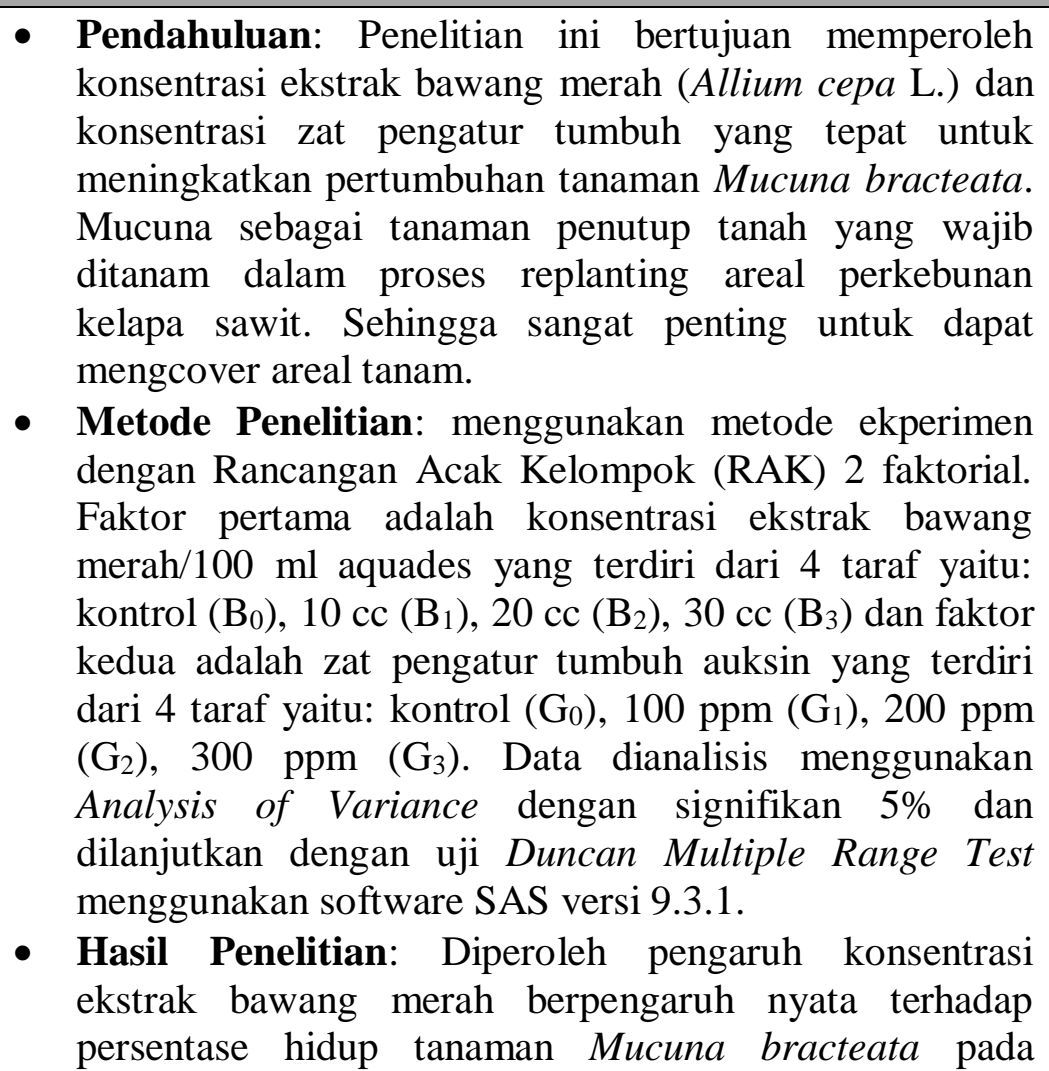 \\
\hline
\end{tabular}




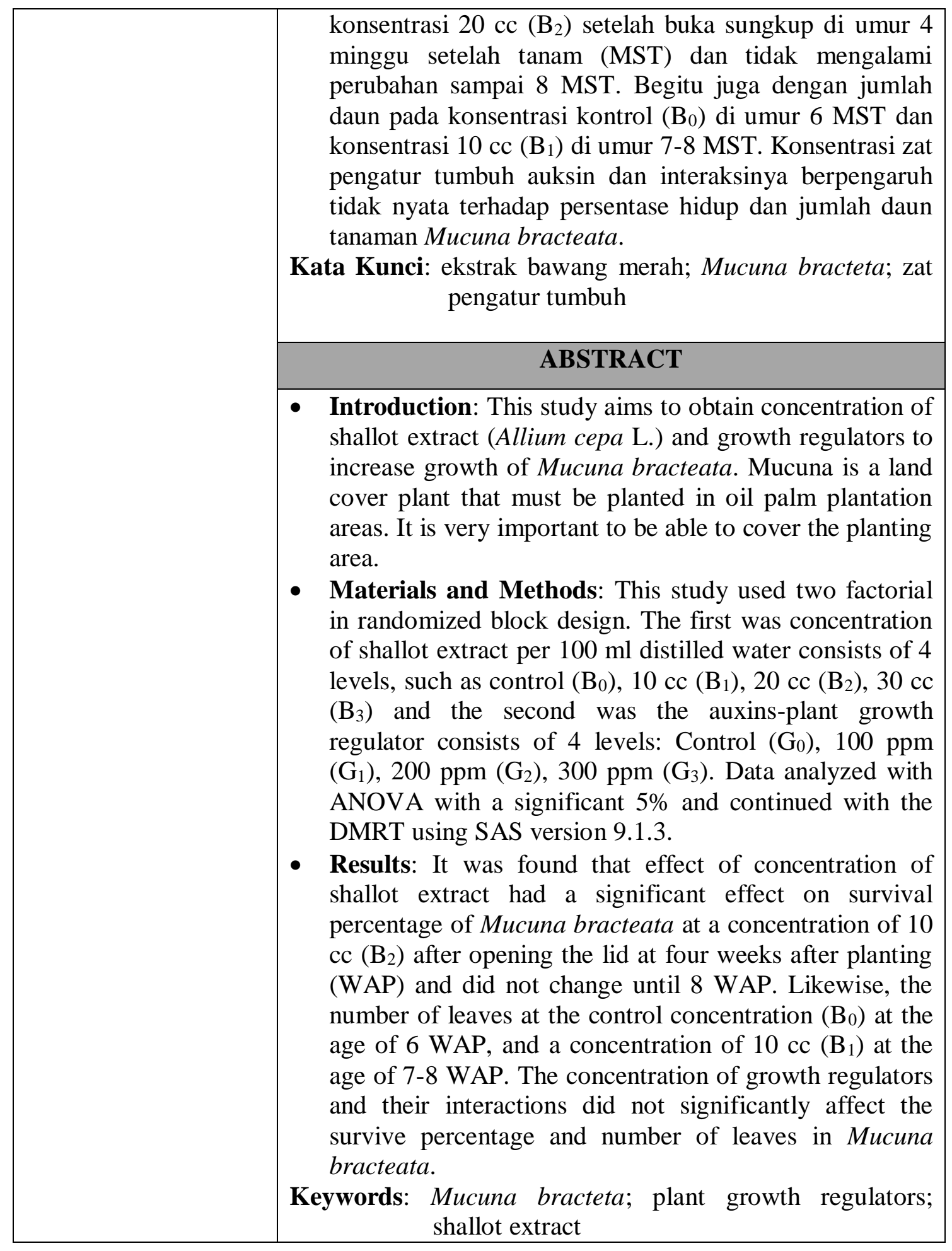

\section{PENDAHULUAN}

Pembukaan lahan baik untuk penanaman baru maupun peremajaan tanaman kelapa sawit menimbulkan perubahan kondisi fisik, kimia dan biologi tanah. Tanah yang terbuka tanpa vegetasi mudah diterpa air hujan dan tersinari matahari secara langsung sehingga mudah mengalami erosi. Salah satu cara mengurangi dampak terpaan 
air hujan dan sinar matahari adalah penanaman tanaman penutup tanah kacangan (Legume Cover Crop/LCC) (Laksono et al., 2016).

Tanaman kacangan yang dapat digunakan salah satunya adalah tanaman Mucuna bracteata D.C. Tanaman Mucuna bracteata D.C merupakan salah satu jenis LCC yang banyak digunakan pada perkebunan kelapa sawit Indonesia. Salah satu tanaman kacangan penutup tanah yang sangat bermanfaat bagi perkebunan kelapa sawit adalah Mucuna bracteata D.C. Karakteristik tanman Mucuna bracteata D.C sebagai tanaman penutup tanah lebih baik dan menguntungkan bila dibandingkan dengan jenis tanaman penutup tanah lainnya, karena dinilai dapat lebih mampu menekan pertumbuhan gulma pesaing (Astari et al., 2014). Salah satu kendala yang dihadapi perkebunan dalam pengembangan LCC adalah terbatasnya ketersediaan benih karena harus diimpor dan harga benih cukup mahal (Siagian, 2012).

Perbanyakannya dapat dilakukan dengan cara perbanyakan vegetatif, salah satunya dengan cara setek (Fauji et al., 2016). Tanaman hasil perbanyakan setek tidak memiliki akar tunggang sehingga kurang kuat pengakarannya. Pemilihan bahan setek penting dilakukan karena berhubungan dengan kecepatan tumbuh akar (Anindito, 2017). Pemberian ZPT auksin pada proses penyetekan Mucuna bracteata D.C bertujuan untuk memperoleh perakaran yang banyak dalam waktu yang relatif cepat. Auksin adalah zat pengatur tumbuh yang berperan dalam proses pemanjangan sel, merangsang pertumbuhan akar, tunas dan daun pada pertumbuhan bibit kelapa sawit (Pratomo et al., 2019).

Bawang merah (Allium cepa L.) merupakan salah satu tumbuhan yang berpotensi untuk digunakan sebagai zat pengatur tumbuh alami karena pada bawang merah mengandung hormon auksin yang dapat memacu pertumbuhan akar pada setek tanaman, pada umbi bawang merah mengandung vitamin B1 (Thiamin) yang berguna untuk pertumbuhan tunas, dan asam nikotinat sebagai koenzim (Marfirani et al., 2014).

Zat pengatur tumbuh (Growtone) merupakan salah satu hormon yang komersial mengandung bahan aktif auksin, yaitu hormon tanaman seperti indolasetat yang berfungsi untuk merangsang pembesaran sel dan merangsang pertumbuhan akar pada tanaman setekan atau cangkokan (Sari et al., 2014). Zat pengatur tumbuh auksin berpengaruh sangat nyata terhadap daya kecambah, potensi tumbuh, indeks vigor, tinggi kecambah dan panjang akar tanaman (Adnan et al., 2017). Sebagian besar molekul zat pengatur tumbuh dapat mempengaruhi metabolisme dan perkembangan sel-sel tumbuhan.

Berdasarkan dari beberapa temuan diatas, penulis tertarik untuk melakukan kajian lanjutan tentang kontribusi konsentrasi ektrak bawang merah (Allium cepa L.) dan konsentrasi zat pengatur tumbuh auksin terhadap pertumbuhan tanaman Mucuna bracteta D.C. Tujuan penelitian ini yaitu mendapatkan konsentrasi ekstrak bawang merah (Allium cepa L.), konsentrasi zat pengatur tumbuh auksin dan interaksinya yang tepat untuk meningkatkan pertumbuhan tanaman Mucuna bracteata D.C. 


\section{BAHAN DAN METODE}

\section{Area Penelitian}

Penelitian ini dilaksanakan di lahan percobaan Jalan Satria, Kecamatan Deli Tua, Kabupaten Deli Serdang, dan dilanjutkan dilaboratorium Universitas Sumatera Utara (USU). Penelitian ini dilakukan pada bulan Maret-Mei 2021.

\section{Alat dan Bahan}

Alat yang digunakan pada penelitian ini adalah timbangan analitik, blender, ayakan 8 mesh, cutter, cangkul, gembor, ember, meteran, gelas ukur, polybag $15 \mathrm{x}$ $21 \mathrm{~cm}$, paranet, tali rafia, tali putih, bambu, kamera, parang, penggaris dan alat tulis. Bahan yang digunakan dalam penelitian ini adalah, bawang merah (Allium cepa L.), zat pengatur tumbuh auksin dengan produk Growtone, setek batang Mucuna bracteata D.C. Pembuatan Ekstrak Bawang Merah

Diblender $2 \mathrm{~kg}$ bawang merah hingga halus lalu tambahkan 1,2 liter aquades dan aduk hingga merata. Setelah merata, selanjutnya larutan disaring agar terpisah dari ampasnya. Sehingga diperoleh ekstrak bawang merah sebanyak 2 liter. Cairan yang telah terpisah dari ampasnya adalah zat pengatur tumbuh alami yang siap untuk digunakan.

\section{Penyiapan Zat Pengatur Tumbuh}

Pembuatan larutan ZPT auksin dibuat dengan mencampurkan 1 liter aquades dengan konsentrasi yang digunakan.

\section{Metode Penelitian}

Ekstrak bawang merah dan ZPT auksin diberikan saat perendaman setek mucuna. Penelitian ini menggunakan Rancangan Acak Kelompok (RAK) faktorial, dengan 2 faktor yang akan diteliti. Faktor I adalah Konsentrasi ekstrak bawang merah (B) yang terdiri dari 4 taraf yaitu: Tanpa perlakuan $\left(\mathrm{B}_{0}\right), 10 \mathrm{cc} / 100 \mathrm{ml}$ aquades $\left(\mathrm{B}_{1}\right), 20 \mathrm{cc} / 100 \mathrm{ml}$ aquades $\left(\mathrm{B}_{2}\right), 30 \mathrm{cc} / 100 \mathrm{ml}$ aquades $\left(\mathrm{B}_{3}\right)$. Faktor II adalah Konsentrasi zat pengatur tumbuh auksin $(\mathrm{G})$ yang terdiri dari 4 taraf yaitu: tanpa perlakuan $\left(\mathrm{G}_{0}\right), 100 \mathrm{ppm}\left(\mathrm{G}_{1}\right)$, $200 \operatorname{ppm}\left(\mathrm{G}_{2}\right), 300 \mathrm{ppm}\left(\mathrm{G}_{3}\right)$.

\section{Parameter Pengamatan}

Parameter yang diamati pada penelitian ini antara lain: (1) persentase hidup (\%)di amati 4 minggu setelah tanam dengan interval satu minggu sekali sampai 8 Minggu Setelah Tanam (MST), (2) jumlah daun (helai) dihitung pada daun yang telah membuka sempurna, dan diamati pada usia tanam 4-8 MST.

\section{HASIL DAN PEMBAHASAN}

\section{Persentase Hidup}

Hasil ANOVA menunjukkan bahwa konsentrasi ekstrak bawang merah (Allium сера L.), berpengaruh nyata terhadap pertumbuhan persentase hidup setek tanaman Mucuna bracteata D.C pada umur 4 Minggu Setelah Tanam (MST) dan tidak mengalami penambahan persentase hidup sampai umur 8 MST. Konsentrasi ZPT auksin dan interaksinya berpengaruh tidak nyata terhadap pertumbuhan persentase hidup tanaman Mucuna bracteata D.C pada umur 4-8 MST, dapat dilihat pada Tabel 1. 
Tabel 1. Pengaruh konsentrasi ektrak bawang merah, zat pengatur tumbuh auksin dan interaksinya terhadap persentase hidup setek tanaman Mucuna bracteata D.C.

\begin{tabular}{cccccc}
\hline Konsentrasi Ekstrak & \multicolumn{3}{c}{ Konsentrasi ZPT auksin $(\mathrm{ppm})$} & \multirow{2}{*}{ Rataan } \\
\cline { 2 - 5 } Bawang Merah $(\mathrm{cc})$ & 0 & 100 & 200 & 300 & \\
\hline 0 & $50,00 \mathrm{tn}$ & $50,00 \mathrm{tn}$ & $62,50 \mathrm{tn}$ & $75,00 \mathrm{tn}$ & $59,38 \mathrm{~b}$ \\
10 & $75,00 \mathrm{tn}$ & $87,50 \mathrm{tn}$ & $87,50 \mathrm{tn}$ & $75,00 \mathrm{tn}$ & $81,25 \mathrm{a}$ \\
20 & $87,50 \mathrm{tn}$ & $87,50 \mathrm{tn}$ & $75,00 \mathrm{tn}$ & $87,50 \mathrm{tn}$ & $84,38 \mathrm{a}$ \\
30 & $75,00 \mathrm{tn}$ & $87,50 \mathrm{tn}$ & $87,50 \mathrm{tn}$ & $87,50 \mathrm{tn}$ & $84,38 \mathrm{a}$ \\
\hline Rataan & $71,88 \mathrm{tn}$ & $78,13 \mathrm{tn}$ & $78,13 \mathrm{tn}$ & $81,25 \mathrm{tn}$ & \\
\hline
\end{tabular}

Keterangan: angka yang diikuti huruf yang berbeda menunjukkan berdampak nyata pada uji DMRT taraf $5 \% . \mathrm{tn}=$ berpengaruh tidak nyata.

\section{Jumlah Daun}

Hasil menunjukkan bahwa konsentrasi ekstrak bawang merah (Allium cepa L.), berpengaruh nyata terhadap pertumbuhan jumlah daun setek tanaman Mucuna bracteata D.C pada umur 6-8 MST, namun berpengaruh tidak nyata pada umur 4-5 MST. Konsentrasi ZPT auksin dan interaksinya berpengaruh tidak nyata terhadap pertumbuhan jumlah daun setek tanaman Mucuna bracteata D.C pada umur 4-8 MST (Tabel 2).

Tabel 2. Pengaruh konsentrasi ektrak bawang merah, ZPT auksin dan interaksinya terhadap pertumbuhan jumlah daun Mucuna bracteata D.C umur 4-8 MST.

\begin{tabular}{|c|c|c|c|c|c|}
\hline \multirow{2}{*}{$\begin{array}{c}\text { Konsentrasi Ekstrak } \\
\text { Bawang Merah }\end{array}$} & \multicolumn{4}{|c|}{ Konsentrasi ZPT auksin (ppm) } & \multirow{2}{*}{ Rataan } \\
\hline & 0 & 100 & 200 & 300 & \\
\hline & \multicolumn{4}{|c|}{$4 \mathrm{MST}$} & \\
\hline 0 & $7,50 \mathrm{tn}$ & $6,75 \mathrm{tn}$ & $8,25 \mathrm{tn}$ & $10,00 \mathrm{tn}$ & 8,13 tn \\
\hline 10 & $10,50 \mathrm{tn}$ & $9,63 \mathrm{tn}$ & $8,46 \mathrm{tn}$ & $9,50 \mathrm{tn}$ & 9,52 tn \\
\hline 20 & $7,63 \mathrm{tn}$ & $6,50 \mathrm{tn}$ & $7,83 \mathrm{tn}$ & $6,33 \mathrm{tn}$ & 7,07 tn \\
\hline 30 & $9,00 \mathrm{tn}$ & $6,25 \mathrm{tn}$ & $8,50 \mathrm{tn}$ & $6,42 \mathrm{tn}$ & $7,54 \mathrm{tn}$ \\
\hline \multirow[t]{2}{*}{ Rataan } & $8,66 \mathrm{tn}$ & $7,28 \mathrm{tn}$ & $8,26 \mathrm{tn}$ & $8,06 \mathrm{tn}$ & \\
\hline & \multicolumn{4}{|c|}{$5 \mathrm{MST}$} & \\
\hline 0 & $9,00 \mathrm{tn}$ & $7,25 \mathrm{tn}$ & $10,00 \mathrm{tn}$ & $12,00 \mathrm{tn}$ & $9,56 \mathrm{tn}$ \\
\hline 10 & $12,50 \mathrm{tn}$ & $12,13 \mathrm{tn}$ & 9,92 tn & $12,17 \mathrm{tn}$ & $11,68 \mathrm{tn}$ \\
\hline 20 & $9,50 \mathrm{tn}$ & $7,88 \mathrm{tn}$ & $9,83 \mathrm{tn}$ & $7,71 \mathrm{tn}$ & 8,73 tn \\
\hline 30 & $12,67 \mathrm{tn}$ & $7,63 \mathrm{tn}$ & $11,88 \mathrm{tn}$ & $7,67 \mathrm{tn}$ & $9,96 \mathrm{tn}$ \\
\hline \multirow[t]{2}{*}{ Rataan } & $10,92 \mathrm{tn}$ & $8,72 \mathrm{tn}$ & $10,41 \mathrm{tn}$ & $9,89 \mathrm{tn}$ & \\
\hline & \multicolumn{4}{|c|}{$6 \mathrm{MST}$} & \\
\hline 0 & $10,50 \mathrm{tn}$ & $10,25 \mathrm{tn}$ & $14,50 \mathrm{tn}$ & $14,50 \mathrm{tn}$ & $12,44 \mathrm{ab}$ \\
\hline 10 & $13,00 \mathrm{tn}$ & $18,13 \mathrm{tn}$ & $12,96 \mathrm{tn}$ & $14,67 \mathrm{tn}$ & $14,69 \mathrm{a}$ \\
\hline 20 & $12,88 \mathrm{tn}$ & $8,75 \mathrm{tn}$ & $9,83 \mathrm{tn}$ & $8,96 \mathrm{tn}$ & $10,11 b$ \\
\hline 30 & $13,67 \mathrm{tn}$ & $10,38 \mathrm{tn}$ & $14,25 \mathrm{tn}$ & 10,92 tn & $12,31 \mathrm{ab}$ \\
\hline \multirow[t]{2}{*}{ Rataan } & $12,51 \mathrm{tn}$ & $11,88 \mathrm{tn}$ & $12,89 \mathrm{tn}$ & $12,26 \mathrm{tn}$ & \\
\hline & \multicolumn{4}{|c|}{$7 \mathrm{MST}$} & \\
\hline 0 & $19,50 \mathrm{tn}$ & $13,25 \mathrm{tn}$ & $17,50 \mathrm{tn}$ & $18,33 \mathrm{tn}$ & $17,15 a b$ \\
\hline 10 & $17,00 \mathrm{tn}$ & $23,28 \mathrm{tn}$ & $17,83 \mathrm{tn}$ & $19,33 \mathrm{tn}$ & $19,36 \mathrm{a}$ \\
\hline 20 & $17,13 \mathrm{tn}$ & $11,38 \mathrm{tn}$ & $14,50 \mathrm{tn}$ & $13,21 \mathrm{tn}$ & $14,06 \mathrm{~b}$ \\
\hline 30 & $19,67 \mathrm{tn}$ & $14,75 \mathrm{tn}$ & $17,00 \mathrm{tn}$ & $15,13 \mathrm{tn}$ & $16,64 \mathrm{ab}$ \\
\hline Rataan & $18,33 \mathrm{tn}$ & $15,67 \mathrm{tn}$ & $16,71 \mathrm{tn}$ & $16,50 \mathrm{tn}$ & \\
\hline
\end{tabular}




\begin{tabular}{cccccc}
\hline \multicolumn{6}{c}{$8 \mathrm{MST}$} \\
0 & $22,50 \mathrm{tn}$ & $17,75 \mathrm{tn}$ & $27,00 \mathrm{tn}$ & $26,33 \mathrm{tn}$ & $23,40 \mathrm{ab}$ \\
10 & $21,50 \mathrm{tn}$ & $30,75 \mathrm{tn}$ & $23,04 \mathrm{tn}$ & $26,50 \mathrm{tn}$ & $25,45 \mathrm{a}$ \\
20 & $23,38 \mathrm{tn}$ & $15,38 \mathrm{tn}$ & $20,67 \mathrm{tn}$ & $17,21 \mathrm{tn}$ & $19,16 \mathrm{~b}$ \\
30 & $25,33 \mathrm{tn}$ & $19,25 \mathrm{tn}$ & $20,25 \mathrm{tn}$ & $21,17 \mathrm{tn}$ & $22,00 \mathrm{ab}$ \\
\hline Rataan & $23,18 \mathrm{tn}$ & $20,78 \mathrm{tn}$ & $23,24 \mathrm{tn}$ & $22,80 \mathrm{tn}$ & \\
\hline
\end{tabular}

Keterangan: angka yang diikuti huruf yang berbeda menunjukkan berdampak nyata pada uji DMRT taraf $5 \%$. $\mathrm{tn}=$ berpengaruh tidak nyata.

\section{Pembahasan}

\section{Persentase Hidup}

Tabel 1 menunjukkan bahwa pengaruh konsentrasi ektrak bawang merah (Allium cepa L.) signifikan meningkatkan persentase hidup tanaman Mucuna bracteta D.C dan tertinggi terdapat pada konsentrasi $20 \mathrm{cc} / 100 \mathrm{ml}$ aquades $\left(\mathrm{B}_{2}\right)$ pada umur 4-8 MST. Pengaruh konsentrasi ZPT auksin berpengaruh tidak nyata terhadap persentase hidup tanaman Mucuna bracteata D.C dan tertinggi terdapat pada 300 ppm $\left(\mathrm{G}_{3}\right)$ di umur 4-8 MST. Interaksi konsentrasi ektrak bawang merah (Allium cepa L.) $20 \mathrm{cc} / 100 \mathrm{ml}$ aquades dan konsentrasi ZPT auksin 300 ppm $\left(\mathrm{B}_{2} \mathrm{G}_{3}\right)$ menunjukkan persentase hidup tanaman Mucuna bracteata D.C tertinggi dibandingkan kombinasi lainnya

Pemberian ekstrak bawang merah (Allium cepa L.) memberikan pengaruh nyata sebesar $(84,38 \%)$ diperoleh dari taraf perlakuan $20 \mathrm{cc} / 100 \mathrm{ml}$ aquades $\left(\mathrm{B}_{2}\right)$ ekstrak bawang merah, perlakuan ini memberikan pengaruh berbeda nyata terhadap taraf perlakuan tanpa ekstrak bawang merah $0 \mathrm{cc} / 100 \mathrm{ml}$ aquades $\left(\mathrm{B}_{0}\right)$ dengan persentase keberhasilan hidup setek tanaman Mucuna bracteata D.C sebesar (59,38\%) setelah buka sungkup. Hal ini dikarenakan pemberian konsentrasi ektrak bawang merah dengan tepat dapat medorong pertumbuhan tanaman Mucuna bracteata D.C.

Menurut Marfirani et al., (2014) bawang merah merupakan salah satu tumbuhan yang dapat di ekstrak untuk dijadikan zat pengatur tumbuh alami, karena pada bawang merah mengandung hormon auksin yang dapat memacu pertumbuhan akar pada setek tanaman. Umbi bawang merah mengandung vitamin B1 (Thiamin) untuk pertumbuhan tunas, riboflavin untuk pertumbuhan, asam nikotinat sebagai koenzim, serta mengandung zat pengatur tumbuh auksin dan rhizokalin yang dapat merangsang pertumbuhan akar.Pernyataan ini sependapat dengan penelitian sebelumnya, yang menyatakan bahwa ekstrak bawang merah diaplikasikan pada tanaman mawar yang di setek dan hasilnya pertumbuhan daun pada tanaman yang di setek dan diberikan ekstrak bawang merah menghasilkan pengaruh terhadap pertumbuhan daun pada setek mawar (Alimudin et al., 2017).

Hormon auksin yang terkandung dalam ektrak bawang merah dapat merangsang pertumbuhan tanaman. Berdasarkan pengaruh pemberian larutan ekstrak bawang merah $20 \mathrm{cc} / 100 \mathrm{ml}$ aquades $\left(\mathrm{B}_{2}\right)$ dengan hasil persentase hidup tertinggi, disebabkan oleh aktivitas auksin yang dapat memenuhi kebutuhan untuk pertumbuhan tanaman Mucuna bracteata D.C. Pernyataan ini sependapat dengan peneliti sebelumnya Pratomo et al., (2018) bahwa peningkatan pertumbuhan tanaman diduga dipengaruhi oleh pemberian 
auksin yang terdapat di dalam ekstrak bawang merah yang berfungsi untuk merangsang pertumbuhan sel tanaman.

Zat pengatur tumbuh (Growtone) dapat berpengaruh secara efektif pada konsentrasi tertentu. Jika konsentrasi yang digunakan terlalu tinggi maka akan dapat merusak setek pada tanaman, karena pembelahan sel dan kalus akan berlebihan sehingga menghambat pertumbuhan akar dan daun, sedangkan bila konsentrasi yang digunakan di bawah optimum maka ZPT tersebut tidak akan berjalan dengan efektif (Khair et al., 2013).

\section{Jumlah Daun}

Tabel 2 menunjukkan bahwa pengaruh konsentrasi ektrak bawang merah (Allium cepa L.) signifikan meningkatkan jumlah daun tanaman Mucuna bracteta D.C dan tertinggi terdapat pada konsentrasi kontrol $\left(\mathrm{B}_{0}\right)$ sebesar 12,43 helai di umur 6 MST, dan konsentrasi $10 \mathrm{cc} / 100 \mathrm{ml}$ aquades $\left(\mathrm{B}_{1}\right)$ sebesar 19,38 helai di umur 7 MST dan sebesar 25,45 helai di umur 8 MST. Pengaruh konsentrasi ZPT auksin berpengaruh tidak nyata terhadap jumlah daun tanaman Mucuna bracteata D.C di umur 4-8 MST. Interaksi konsentrasi ektrak bawang merah (Allium cepa L.) dan konsentrasi ZPT auksin berpengaruh tidak nyata terhadap pertumbuhan jumlah daun tanaman Mucuna bracteata D.C pada umur 4-8 MST.

Pemberian ekstrak bawang merah (Allium cepa L.) memberikan pengaruh nyata dengan rataan sebesar (20,18 helai) diperoleh dari taraf perlakuan $10 \mathrm{cc} / 100 \mathrm{ml}$ aquades $\left(B_{1}\right)$ ekstrak bawang merah, perlakuan ini memberikan pengaruh berbeda nyata terhadap taraf perlakuan tanpa ekstrak bawang merah $0 \mathrm{cc} / 100 \mathrm{ml}$ aquades $\left(\mathrm{B}_{0}\right)$ dengan pertumbuhan jumlah daun setek tanaman Mucuna bracteta D.C dengan rataan sebesar (17,57 helai) pada umur 4-8 MST. Hal ini disebabkan karena panjang sulur dan jumlah sulur mempengaruhi jumlah daun, semakin panjang sulur dan semakin banyak jumlah sulur tanaman maka jumlah daun akan semakin meningkat.

Kandungan auksin yang terdapat pada larutan ekstrak bawang merah dapat mendorong pertumbuhan setek tanaman. Selain berperan pada pembentukan tunas, tinggi tunas dan pembentukan akar juga berperan dalam pembentukan daun. Jumlah daun terbanyak menunjukkan tanaman mengalami pertumbuhan dan perkembangan yang baik (Utami et al., 2015). Tunas yang tumbuh lebih panjang akan memiliki tempat tumbuh daun yang lebih banyak dibandingkan dengan tunas yang pendek. Menurut Tarigan et al., (2017) cepat lambatnya saat muncul tunas akan mempengaruhi panjang tunas, sehingga tunas yang tumbuh lebih cepat dapat menghasilkan tunas yang lebih panjang, dengan tunas yang lebih panjang maka berpotensi untuk tumbuhnya daun lebih banyak, Tunas yang tumbuh lebih panjang akan memiliki tempat tumbuh daun yang lebih banyak dibandingkan dengan tunas yang pendek.

\section{KESIMPULAN}

Konsentrasi ekstrak bawang merah (Allium cepa L.) berpengaruh nyata terhadap parameter persentase hidup (\%) pada konsentrasi $20 \mathrm{cc} / 100 \mathrm{ml}$ aquades $\left(\mathrm{B}_{2}\right)$ di umur 4- 
8 MST dan jumlah daun (helai) pada konsenstrasi kontrol $\left(\mathrm{B}_{0}\right)$ di umur 6 MST, serta konsentrasi $10 \mathrm{cc} / 100 \mathrm{ml}$ aquades $\left(\mathrm{B}_{1}\right)$ setek tanaman Mucuna bracteata D.C. Konsentrasi ZPT auksin dan inetraksinya berpengaruh tidak nyata terhadap semua parameter, namun perlakuan konsentrasi 300 ppm $\left(\mathrm{G}_{3}\right)$ menunjukkan persentase hidup tanaman Mucuna bracteta D.C tertinggi, Interaksi konsentrasi ekstrak bawang merah 10 $\mathrm{cc} / 100 \mathrm{ml}$ aquades dan konsentrasi ZPT auksin $100 \mathrm{ppm}\left(\mathrm{B}_{2} \mathrm{G}_{3}\right)$ menunjukkan persentase hidup tanaman Mucuna bracteata D.C tertinggi dibandingkan kombinasi lainnya.

\section{UCAPAN TERIMA KASIH}

Penulis mengucapkan terima kasih kepada laboratorium Universitas Sumatera Utara (USU) yang telah membantu menyelesaikan penelitian penulis.

\section{DAFTAR PUSTAKA}

Adnan., Juanda, B. R., \& Zaini, M. (2017). Pengaruh konsentrasi dan lama perendaman dalam ZPT auksin terhadap viabilitas benih semangka (Citurullus lunatus) kadaluarsa. Jurnal Penelitian Agrosamudra, 4(1), 45-57. https://www.ejurnalunsam.id/index.php/jagrs/article/view/188.

Alimudin., Syamsiah, M., \& Ramli. (2017). Aplikasi pemberian ekstrak bawang merah (Allium cepa L.) terhadap pertumbuhan akar setek batang bawah mawar (Rosa Sp.) varietas malltic. Journal Agroscience, 7(1), 194-202. https://doi.org/10.35194/agsci.v7i1.52.

Anindito, A. S. (2017). Pengaruh jenis bahan tanam dan konsentrasi rootone-F terhadap keberhasilan pertumbuhan Mucuna bracteata DC. Buletin Agrohorti, 5(2), 226233. https://doi.org/10.29244/agrob.v5i2.16803.

Astari, R. P., Rosmayati, R., \& Sartini, E. (2014). Pengaruh pematahan dormansi secara fisik dan kimia terhadap kemampuan berkecambah benih mucuna (Mucuna bracteata DC). Jurnal Online Agroekoteknologi, 2(2), 803-812..

Fanesa, A. (2011). Pengaruh pemberian beberapa zat pengatur tumbuh terhadap pertumbuhan setek pucuk jeruk kacang (Citrus nobilis L.). Skripsi. Universitas Andalas, Padang.

Fauzi, R., Meiriani., \& Barus, A. (2016). Pengaruh persentase naungan terhadap pertumbuhan bibit Mucuna bracteata DC asal setek dengan konsentrasi IAA yang berbeda. Jurnal Online Agroekoteknologi, 4(3), 2114-2126. https://talenta.usu.ac.id/joa/article/view/2133.

Khair, H., Meizal., \& Hamdani, Z. R. (2013). Pengaruh konsentrasi ekstrak bawang merah dan air kelapa terhadap pertumbuhan stek tanaman melati putih (Jasminum sambac L.). AGRIUM: Jurnal Ilmu Pertanian, 18(2), 130-138. http://dx.doi.org/10.30596\%2Fagrium.v18i2.354.

Laksono, P. B., Wachjar, A., \& Supijatno. (2016). Pertumbuhan Mucuna bracteata DC. pada berbagai waktu inokulasi dan dosis inokulan. Jurnal Agronomi Indonesia, 44(1), 104-110. https://doi.org/10.24831/jai.v44i1.12510.

Marfirani, M., Rahayu, Y. S., \& Ratnasari, E. (2014). Pengaruh pemberian berbagai konsentrasi filtrat umbi bawang merah dan rootone-F terhadap pertumbuhan stek melati "Rato Ebu". LenteraBio: Berkala Ilmiah Biologi, 3(1), 73-76. https://jurnalmahasiswa.unesa.ac.id/index.php/lenterabio/article/view/7093. 
Pratomo, B., Aji, S., \& Agustina, L. T. (2019). Respon ekstrak ubi jalar (Ipomoea batatas) dan bubur pisang sebagai ZPT hayati pada pertumbuhan bibit kelapa sawit (Elaeis guineensis Jacq) pada pre nursery. Agroprimatech, 3(1), 37-45. http://jurnal.unprimdn.ac.id/index.php/Agroprimatech/article/view/822.

Pratomo, B., Arfianti, S., \& Sihombing, H. S. (2018). Pengaruh pemberian kompos ampas tebu dan ekstrak rebung bambu terhadap pertumbuhan bibit kelapa sawit (Elaeis guineensis Jacq.) di pre nursery. Agroprimatech, 1(2), 79-90. http://jurnal.unprimdn.ac.id/index.php/Agroprimatech/article/view/765.

Sari, H. P., Hanum, C., \& Charloq. (2014). Daya kecambah dan pertumbuhan Mucuna bracteata melalui pematahan dormansi dan pemberian zat pengatur tumbuh giberelin $\left(\mathrm{GA}_{3}\right)$ v. Jurnal Online Agroekoteknologi, 2(2), 630-644.

Siagian, N. (2012). Perbanyakan tanaman kacangan penutup tanah Mucuna bracteata melalui benih, stek batang dan penyusuan. Warta Perkaretan, 31(1), 21-34.

Tarigan. P. L, Nurbaiti., \& Yoseva, S. (2017). Pemberian ekstrak bawang merah sebagai zat pengatur tumbuh alami pada pertumbuhan setek lada (Piper ningrum L.). Jurnal Online Mahasiswa Fakultas Pertanian, 4(1), 1-11. https://jom.unri.ac.id/index.php/JOMFAPERTA/article/view/16795.

Utami, E. S. W., Purnobasuki, H., Soedarti, T., \& Haryanto, S. (2015). Asymbiotic seed germination and in vitro seedling development of Paphiopedilum liemianum Fowlie, an endangered terrestrial orchid in Northern Sumatra, Indonesia. Journal of Plant Sciences, 10(1), 25-34. https://dx.doi.org/10.3923/jps.2015.25.34. 